\title{
Motor imagery and swallowing: a systematic literature review
}

\author{
Ada Salvetti Cavalcanti Caldas ${ }^{(1)}$ \\ Weldma Karlla Coelho(1) \\ Roberta Gomes Ferreira Ribeiro(1) \\ Daniele Andrade da Cunha(2) \\ Hilton Justino da Silva(2)
}

(1) Instituto de Medicina Integral Professor Fernando Figueira - IMIP, Recife, Pernambuco, Brasil .

(2) Universidade Federal de Pernambuco UFPE, Recife, Pernambuco, Brasil.

Conflict of interests: Nonexistent

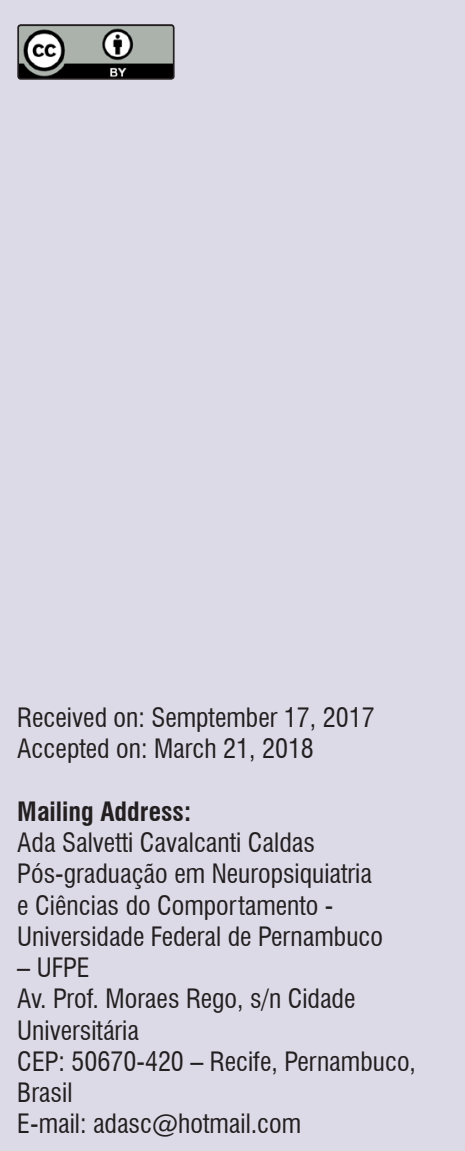

\section{ABSTRACT}

Objetive: to identify, in the literature, studies that address the use of motor imagery of swallowing.

Methods: a systematic review in SCOPUS databases, Science Direct and Medline, with descriptors and free terms "Motor Imagery"; "Swallow"; "Feeding"; "Stomatognathic System"; "mastication", "Chew"; "Deglutition"; "Deglutition Disorders"; and "Mental Practice". Original articles using the motor imagery of swallowing were included, while reviews were excluded. For data analysis, at the first and second steps, the reading of titles and abstracts of the studies was carried out. In the third step, all studies that were not excluded were read in full.

Results: Four manuscripts were selected. The use of motor imagery in the rehabilitation of swallowing shows to be a recent proposal (2014-2015). The sample was reduced and comprised mainly healthy individuals. The EMG of the supra-hyoid muscles was used in two manuscripts. The most used neuroimaging technique was the Near-Infrared Spectroscopy, demonstrating the occurrence of hemodynamic changes during motor imagery and motor execution of swallowing.

Conclusion: the motor imagery produces brain response in the motor area of the brain, suggesting that mentalization of actions related to swallowing is effective. However, further studies are needed for the application of this approach in the swallowing rehabilitation.

Keywords: Stomatognathic System; Swallow; Mastication; Deglutition Disorders; Feeding 


\section{INTRODUCTION}

Swallowing is an essential function for the maintenance of life, fundamental in the intake and absorption of nutrients by the body. Thus, during swallowing smooth and safe passage of food and saliva from the oral cavity to the oropharynx occurs through a sequence of coordinated muscle contractions. And thus swallowing can be classified as oral, pharyngeal and esophageal depending on the location of the food bolus ${ }^{1}$. This scheduled activity can be initiated voluntarily or synergistic awakened by movements triggered by sensory impulses from the posterior pharynx ${ }^{2}$.

This whole process has underlying complex neurophysiological mechanisms that require the activation of 55 muscles through six pairs of cranial nerves ${ }^{3}$ and while it may initially be either conscious or unconscious, the final phase of swallowing occurs through blood pressure changes and contractions of contractile muscles of faringe1. These changes are part of a pre-programmed sequence motor suffering specific modulations that rely on sensory feedback arising from the oropharynx, considering the consistency and food size ${ }^{4}$.

In the cortex, swallowing can be represented in the areas of the insula, the premotor cortex and the sensorimotor cortex ${ }^{5}$. This is a complex function, integrating numerous systems: sensory (tactile, olfactory, gustatory and proprioceptive); motor (oral-pharyngeal motor coordination, integration between the components of mastication and breath; tone, range of motion, muscular strength) as well as cognitive components ${ }^{6}$.

The inability or difficulty to swallow can be commonly detected in patients with neurological disorders ${ }^{4}$ and requires motor trainings to favor functional recovery ${ }^{6}$.

In recent years have intensified research with innovative techniques, and conventional approaches, particularly in the field of neurological disorders ${ }^{7,8}$, highlighting the motor imagery (MI).

The $\mathrm{Ml}$ can be conceptualized as a dynamic state during which the representation of a specific motor action is internally activated within a working memory without any motor response ${ }^{9}$, in other words, the individual imagines an action to be performed, describing the sequence of movements needed to perform this task without actually performing any movement. This technique, therefore, is a cognitive strategy that can benefit the acquisition of motor habilities and the functional performance of subjects undergoing rehabilitation ${ }^{10-12}$, still little used to facilitate the feeding activity.
The literature suggests that the $\mathrm{Ml}$ can be an important therapeutic tool to facilitate individuals motor recovery after neurological injury ${ }^{9,12}$. Since $\mathrm{Ml}$ allows you to activate the motor repertoire in all rehabilitation levels, namely acute, sub-acute or chronic disease ${ }^{9}$ fase, can be used as a training strategy for the relearning of Activities of Daily Living (ADL) ${ }^{13}$. This approach is considered as a mental test of kinesthetic properties and / or visual movements ${ }^{9}$ being directly related to the activation of the motor area and areas of the somatosensory cortex ${ }^{12}$.

Studies have shown that $\mathrm{Ml}$ generates changes in motor performance ${ }^{10,11}$ and can be used as a preparatory approach, since it increases the efficiency of subsequent physical training ${ }^{9}$. The hypothesis of these changes in functional performance may be related to the possibility of neural training establishing, in the first phase of muscle training, the increase of muscle strength, caused by adaptive changes in central processes and not by muscle hypertrophy, suggesting that the gains oberved after $\mathrm{Ml}$ are due to neural changes in levels of programming and planning of motor system ${ }^{10}$.

From a neurological point of view, it is already well diffused in the literature that the primary motor area, primarily responsible for the motor, and the motor additional area involved in planning complex sequences are activated during movement execution ${ }^{14}$.

Studies suggest that the pre-motor cortex and primary motor are essential during $\mathrm{Ml}$ as well as in motor execution. Also propose that the primary motor cortex cause more changes in the motor areas during the motor execution (ME) than in the Ml due to interaction with supplementary motor area ${ }^{15-17}$. In summary, the results of different studies have shown that $\mathrm{Ml}$ can increase the performance of motor tasks and that this increase may be associated with physiological and plastic changes of the Central Nervous System.

In this context, Ml directed to the swallowing function can be thought from the understanding of neuroplasticity. Study on the plasticity of the central nervous system after ischemic or mechanical injury discloses that neurological recovery in dysphagia is disrupted from the recruitment of adjacent neurons to the injured brain area, as well as through the activation of distant areas of primary focus with neuronal organization and alignment ipsi- and contralateral ${ }^{18}$, since the cortical representation of the normal swallowing is bilateral ${ }^{19}$.

Thus, the literature indicates that the shared brain activation by areas of swallowing and speaking 
elevation suggest the possibility of using the motor imagery of the tongue protrusion movement as a means of practicing the motor imagery swallowing, revealing even that the input sensory language and swallowing are similar ${ }^{6}$. In this way, the $\mathrm{Ml}$ of the swallowing is based on the principles of neuroplasticity, considering also the oral phase of swallowing, in which the position of the alimentary bolus in the tongue occurs and the ejection of the bolus into the pharynx voluntarily, in a coordinated sequence of muscular contractions ${ }^{2}$.

Understanding the association between $\mathrm{Ml}$ and feeding activity can enhance the swallowing rehabilitation process of individuals after stroke, contributing to the clinical practice of professionals, and highlighting speech therapists involved in treating these individuals. In this context, this study aims to identify the literature studies that address the use of motor imagery function during the swallowing function.

\section{METHODS}

The systematic review of the literature was performed using the SCOPUS, Science and Medical Literature Direct Analysis and Retrieval System Online (Medline) databases, through the PUBMED platform. The data search was performed by three independent researchers, having occurred from September 2016 to January 2017. A specific strategy has been drawn up to the intersection of the descriptors (DeCS / MeSH) keywords for the scientific literature subjects recovery and Free-Terms (FT) - terms not found in DeCS and $\mathrm{MeSH}$, but of relevance to the search.

In all databases, a strategy of search was performed with the syntax: "Motor Imagery" (FT) AND "Swallow" (FT); "Motor Imagery" (FT) AND "Feeding" (DeCS); "Motor Imagery" (FT) AND "Stomatognathic System"(MeSH); "Motor Imagery" (FT) AND "mastication "(MeSH); "Motor Imagery" (FT) AND "Chew "(FT); "Motor Imagery" (FT) AND "Deglutition "(MeSH); "Motor imagery" (FT) AND "Deglutition Disorders "(MeSH). The crossings above were also performed with the free term "Mental Practice" by replacing the term "Motor Imagery" (FT).

The inclusion criteria for the studies found by searching the databases were: original articles; address the use of motor imagery rehabilitation of swallowing, the feeding activity and / or stomatognathic system components related to this activity, without language and period restriction. Systematic reviews were excluded, as well as articles that addressed the attempted rehabilitation of other parts of the body, without focusing in the activity of swallowing, the feeding or the stomatognathic system components.

This review followed the methodology adopted by Cochrane Brazil, and no filters were added during the search of manuscripts, with no restriction of age, gender or year of publication. According to Cochrane criteria, a systematic review should have a broad literature search in order to identify the greatest number of studies related to the issue, gathering similar data and evaluating it critically the methodology employed, promoting evidence-based practice ${ }^{20}$.

Articles should meet the selection criteria, allowing, on the part of the evaluators, three answers: Yes, No and Maybe. The article that just got «yes» and / or «maybe» by two evaluators was included. On the other hand, the publication with reply «no» by two evaluators deleted the item analysis. The results of the two evaluators were compared and, in the case of disagreement over the article selection, it was requested that the article be assessed by a third expert (judge).

The selection of the articles was conducted in three stages. In the first stage, reading the titles and excluded those who did not fit any of the selection criteria. In the second stage, reading the abstracts of the studies and in the third stage, all the studies that were not excluded were read in full for the selection of those to be included in this review.

\section{LITERATURE REVIEW}

In the Medline database, via PubMed, crossing the keywords and free terms, 387 articles were found, of which, 57 were excluded by repetition. In the SCOPUS database, 476 articles were found (119 repeated articles). In Science Direct database, 77 articles were found, excluding 13 by repetition.

Considering the criteria of inclusion and exclusion, 4 articles were selected for this systematic review ${ }^{6,21-23}$. The flowchart, which shows on detail, this process, follows the model of the Preferred Reporting Items for Systematic Reviews and Meta-Analyzes (PRISMA) ${ }^{24}$ (Figure 1). 

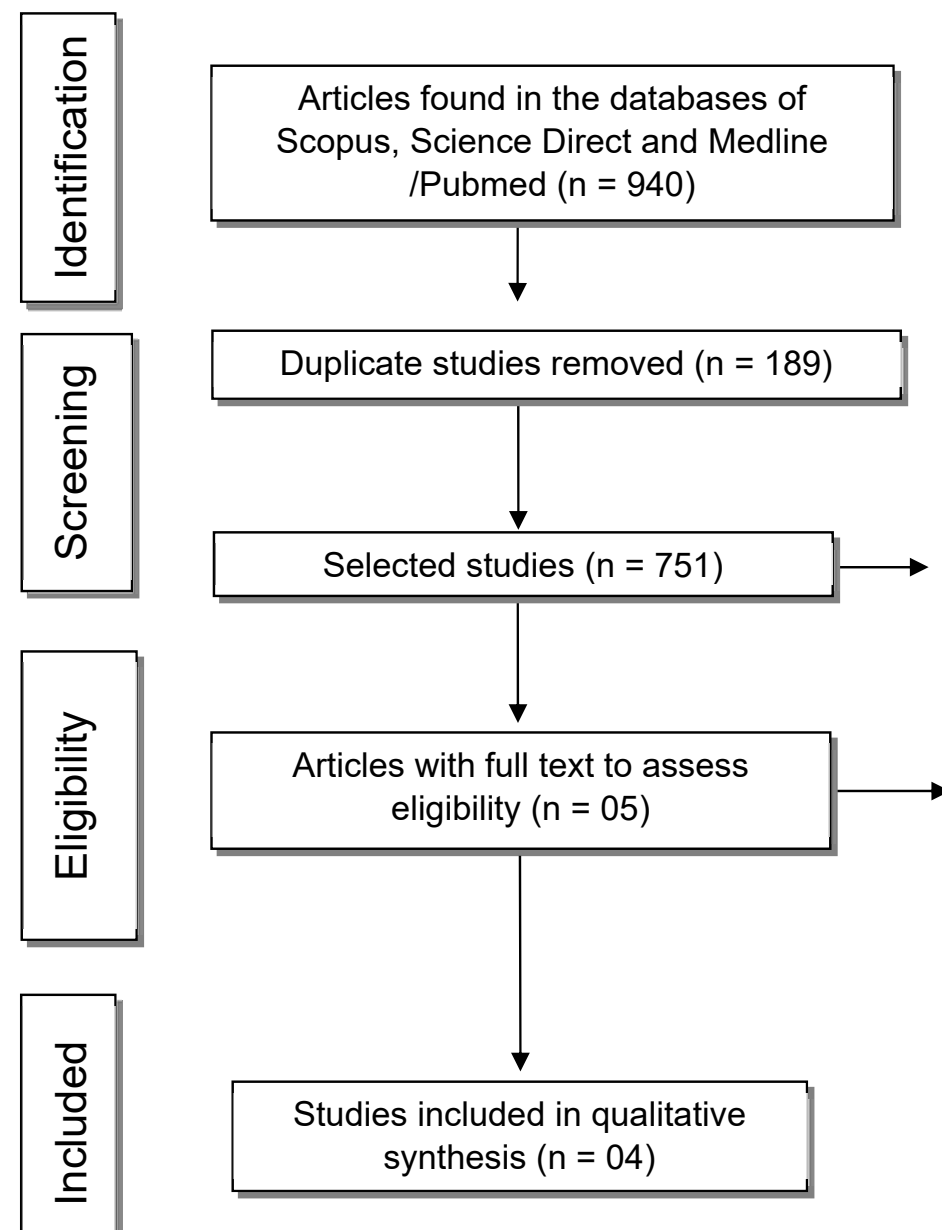

Studies excluded $(n=746)$

728 articles excluded by title 18 articles excluded by abstract

Articles with full text excluded ( $n=01$ )

Article did not use motor imagery as a rehabilitation strategy

Figure 1. Flowchart and criteria for selection and inclusion of articles

For a better presentation of the results, the following variables of the selected articles were considered: author (year); country (sector); objective; subject; age; Inclusion criteria; Exclusion criteria; pathology (time, area, and side of brain injury); functional assessments; technique (imaging); strategy (motor imagery); major brain areas investigated; and results (Figures 2 and 3 ). 


\begin{tabular}{|c|c|c|c|c|c|c|c|}
\hline Authors (year) & $\begin{array}{l}\text { Country } \\
\text { (Sector) }\end{array}$ & Objective & $\begin{array}{c}\text { Subjects - P: } \\
M / W\end{array}$ & $\begin{array}{c}\text { Age (average- } \\
\text { standard deviation) }\end{array}$ & Inclusion Criteria & Exclusion Criteria & $\begin{array}{c}\text { Pathology - Time, area } \\
\text { and side of the brain } \\
\text { lesion }\end{array}$ \\
\hline $\begin{array}{l}\text { Kober; Wood } \\
\text { (2014) }\end{array}$ & $\begin{array}{l}\text { Austria and } \\
\text { Netherlands } \\
\text { (Psychology) }\end{array}$ & $\begin{array}{l}\text { Investigating cerebral } \\
\text { hemodynamics in } \\
\text { response to ME and MI } \\
\text { during swallowing }\end{array}$ & $\begin{array}{l}14 \text { healthy } \\
\text { individuals } \\
(7 / 7)\end{array}$ & 31.86 years & $\begin{array}{l}\text { Right dominant hand; normal } \\
\text { vision or corrected normal vision }\end{array}$ & $\begin{array}{l}\text { Alterations: neurological, } \\
\text { psychiatric, respiratory } \\
\text { or swallowing disorders }\end{array}$ & Does not show \\
\hline $\begin{array}{l}\text { Yang et al., } \\
\text { (2014) }\end{array}$ & $\begin{array}{c}\text { Singapura } \\
\text { (Reabilitação) }\end{array}$ & $\begin{array}{l}\text { To investigate cerebral } \\
\text { hemodynamics in } \\
\text { response to ME and } \\
\text { MI during swallowing } \\
\text { and Ml of tongue } \\
\text { protrusion, in order to } \\
\text { find a proposal for the } \\
\text { rehabilitation of post- } \\
\text { stroke dysphagia }\end{array}$ & $\begin{array}{l}\text { Group } 1 \text { - } 10 \\
\text { (8/2) healthy } \\
\text { individuals } \\
\text { Group } 2 \text { - } 01 \\
\text { man with } \\
\text { dysphagia } \\
\text { due to chronic } \\
\text { stroke }\end{array}$ & $\begin{array}{c}\text { Group } 1-35.9 \pm 7.7 \\
\text { years } \\
\text { Group } 2 \text { - } 56 \text { years }\end{array}$ & $\begin{array}{c}\text { Group } 1 \text { - Healthy individuals; } \\
\text { Group } 2 \text { - Patient with dysphagia } \\
\text { after stroke }\end{array}$ & $\begin{array}{l}\text { Healthy individuals: } \\
\text { respiratory, swallowing } \\
\text { and neurological } \\
\text { disorders; feeding and } \\
\text { nutrition problems }\end{array}$ & $\begin{array}{c}\text { Stroke - } 01 \text { year of } \\
\text { hemorrhagic trunk lesion } \\
\text { (right and midbrain } \\
\text { bridge) }\end{array}$ \\
\hline $\begin{array}{l}\text { Kober et al., } \\
(2015 b)\end{array}$ & $\begin{array}{c}\text { Austria } \\
\text { (Psychology) }\end{array}$ & $\begin{array}{l}\text { To evaluate the effects } \\
\text { of NIRS based on } \\
\text { neurofeedback training } \\
\text { on the patterns of } \\
\text { cortical activation } \\
\text { underlying the } \\
\text { swallowing function }\end{array}$ & $\begin{array}{l}20 \text { healthy } \\
\text { individuals } \\
(10 / 10)\end{array}$ & $\begin{array}{c}\text { Group } 1(\text { oxy-Hb): } \\
23.8 \pm 0.47 \text { years } \\
\text { Group } 2 \text { (desoxy- } \mathrm{Hb}): \\
25.7 \pm 1.20 \text { years }\end{array}$ & $\begin{array}{l}\text { Present normal swallowing } \\
\text { rate }>10 \mathrm{~mL} / \mathrm{s} \text {; normal vision or } \\
\text { corrected normal vision }\end{array}$ & $\begin{array}{l}\text { Alterations: neurological, } \\
\text { psychiatric, respiratory } \\
\text { or swallowing disorders }\end{array}$ & Does not show \\
\hline $\begin{array}{l}\text { Kober et al., } \\
(2015 a)\end{array}$ & $\begin{array}{c}\text { Austria } \\
\text { (Psychology) }\end{array}$ & $\begin{array}{l}\text { To examine cerebral } \\
\text { hemodynamic changes } \\
\text { in response to ME and } \\
\text { Ml of swallowing in } \\
\text { patients with dysphagia } \\
\text { compared to healthy } \\
\text { individuals }\end{array}$ & $\begin{array}{l}\text { Stroke group: } \\
04(1 / 3) ; \\
\text { Control group: } \\
02 \text { healthy } \\
\text { individuals } \\
(1 / 1)\end{array}$ & $\begin{array}{l}\text { Stroke group: } 75 \pm \\
5.29 \text { years } \\
\text { Control group: } 67 \\
\text { year old male and } 64 \\
\text { year old female }\end{array}$ & $\begin{array}{l}\text { Stroke group: Neurological } \\
\text { patients with severe deglutition } \\
\text { abnormalities; injury to any } \\
\text { part of the brain; motor deficit; } \\
\text { injury time of at least } 4 \text { weeks; } \\
\text { Good vision and hearing; } \\
\text { understanding and ability to give } \\
\text { information; presence of family } \\
\text { support. Control group - No } \\
\text { swallowing problem. }\end{array}$ & $\begin{array}{l}\text { Stroke group - Other } \\
\text { concomitant neurological } \\
\text { disorders; dementia } \\
\text { (MMSE <24); } \\
\text { insufficient understanding } \\
\text { and communication; } \\
\text { psychiatric disorders; } \\
\text { heminelect. }\end{array}$ & $\begin{array}{l}\text { Stroke: trunk lesions } \\
\text { (71 days); Right oblong } \\
\text { marrow ( } 114 \text { days); } \\
\text { right middle cerebral } \\
\text { artery ( } 254 \text { days and } \\
71 \text { days) }\end{array}$ \\
\hline
\end{tabular}

Legend: ME: Motor Execution; MI: Motor Imagery; NIRS: Near-Infrared Spectroscopy Study; Oxy-Hb: Oxyhemoglobin; Desoxy-Hb: Deoxyhemoglobin; MMSE: MiniMental State Examination; P: study population; M: Men: W: Women; mL/s: Milliliter per second.

Figure 2. Characterization of the studies that performed the motor imagery of the deglutition activity

\begin{tabular}{|c|c|c|c|c|c|}
\hline Authors (Year) & $\begin{array}{l}\text { Functional } \\
\text { Evaluations }\end{array}$ & $\begin{array}{l}\text { Technique/ } \\
\text { Image }\end{array}$ & Motor Imagery Strategy & $\begin{array}{c}\text { Brain Areas } \\
\text { Studied }\end{array}$ & Results \\
\hline $\begin{array}{l}\text { Kober; Wood } \\
(2014)\end{array}$ & $\begin{array}{l}\text { Use of EMG in supra- } \\
\text { hyoid muscles during } \\
\text { MI, ME and rest }\end{array}$ & NIRS & $\begin{array}{l}\text { MI/ME swallowing: Water use; Use of } \\
\text { flexible tube ( } 3 \mathrm{~mm} \text { diameter contained in } \\
\text { a } 1 \mathrm{~L} \text { bottle of water). ME of } 15 \mathrm{~s} ; 15 \mathrm{~s} \mathrm{IM} \text {; } \\
\text { Rest from } 28 \mathrm{~s} \text { to } 32 \mathrm{~s} \text {. On the screen of a } \\
\text { computer indication of action or rest. }\end{array}$ & $\begin{array}{l}\text { Areas of } \\
\text { Brodmann; }\end{array}$ & $\begin{array}{l}\text { Topography: Change of oxy-Hb and desoxy-H } \\
\text { during Ml and ME. Signal in the lower frontal } \\
\text { gyrus, including the Broca area; } \\
\text { Oxy-Hb higher during rest than during } \\
\mathrm{ME} \text {; - Oxy-Hb increased during Ml and } \\
\text { decreased during Ml; Desoxy-Hb with higher } \\
\text { concentration in tasks than at rest; Desoxy- } \\
\mathrm{Hb} \text { demonstrates positive correlation between } \\
\mathrm{Ml} \text { and ME, mainly in the kinesthetic strategy } \\
\text { of Ml; Pre-motor; Supplemental motor area } \\
\text { and subcentral area were involved in Ml and } \\
\text { ME; It involves the involvement of the insula } \\
\text { during swallowing, not captured by the NIRS; }\end{array}$ \\
\hline $\begin{array}{l}\text { Yang et al., } \\
\text { (2014) }\end{array}$ & $\begin{array}{l}\text { EMG of the submental } \\
\text { and infrahyoid muscles }\end{array}$ & EEG & $\begin{array}{l}03 \text { experimental sessions, each with two } \\
\text { steps for healthy individuals: Sessions } 1 \\
\text { and } 2 \text { with the Ml of swallowing and rest; } \\
\text { Session } 3 \text { with language Ml and home; } \\
02 \text { experimental sessions, each with two } \\
\text { stages for the patient with stroke: one of Ml } \\
\text { of swallowing versus rest and another of Ml } \\
\text { of tongue versus rest } \\
\text { Swallowing Ml: Use of water, juice or food } \\
\text { (noodles or large pill); Ml of the tongue: } \\
\text { Protrusion of the tongue as far as possible } \\
\text { and by several times; Visual track through } \\
\text { a screen and auditory indicating the } \\
\text { beginning of the task to be imagined; }\end{array}$ & $\begin{array}{c}\text { No specific area } \\
\text { was flagged }\end{array}$ & $\begin{array}{l}\text { Accuracy in the classification of } 70.89 \% \text { and } \\
73.79 \% \text { for Ml of swallowing and tongue MI } \\
\text { respectively in healthy individuals; Cross- } \\
\text { validation on average of } 66.40 \% \text { and } 70.24 \% \\
\text { for Ml of swallowing and } \mathrm{Ml} \text { of tongue for } \\
\text { patients with stroke; Strong correlation in the } \\
\text { classification between the Ml of swallowing } \\
\text { versus rest; and Ml of tongue versus rest; it } \\
\text { is possible to perform the swallowing Ml to } \\
\text { enable the rehabilitation of dysphagia in post- } \\
\text { stroke patients; }\end{array}$ \\
\hline
\end{tabular}




\begin{tabular}{|c|c|c|c|c|c|}
\hline Authors (Year) & $\begin{array}{c}\text { Functional } \\
\text { Evaluations }\end{array}$ & $\begin{array}{c}\text { Technique/ } \\
\text { Image }\end{array}$ & Motor Imagery Strategy & $\begin{array}{c}\text { Brain Areas } \\
\text { Studied }\end{array}$ & Results \\
\hline $\begin{array}{c}\text { Kober et al., } \\
(2015 \mathrm{~b})\end{array}$ & MIQ-R & NIRS & $\begin{array}{l}\text { Deglutition test with } 100 \mathrm{~mL} \text { of water } \\
\text { at room temperature; Measurement of } \\
\text { swallowing time; Seven sessions with } \\
\text { NF were performed three to five times } \\
\text { a week for } 20 \text { min; Changes in NIRS } \\
\text { concentrations were shown by moving } \\
\text { a white spot vertically on the feedback } \\
\text { screen depending on the level of oxy- or } \\
\text { desoxy-Hb; Green or gray areas moved } \\
\text { horizontally at constant speed; When the } \\
\text { white point passed through the gray part the } \\
\text { volunteers were instructed to relax; When } \\
\text { the point reached the green area, they were } \\
\text { instructed to imagine swallowing; Before } \\
\text { and after the NF evaluation with NIRS; ME: } \\
\text { swallowing water with small sips using } \\
\text { a } 3 \text { mm diameter flexible tube immersed } \\
\text { in a } 1 \mathrm{~L} \text { bottle (During the first } 15 \mathrm{~s} \text { they } \\
\text { ingested } 5 \text { to } 6 \text { sticks); In Ml, the volunteers } \\
\text { imagined swallowing } 5 \text { to } 6 \text { sticks of water } \\
\text { such as ME; }\end{array}$ & $\begin{array}{l}\text { Bottom frontal } \\
\text { rotation } \\
\text { bilaterally }\end{array}$ & $\begin{array}{l}\text { Participants had an increase in oxy- or deoxy- } \\
\mathrm{Hb} \text { levels relative to motor areas during } \\
\text { swallowing Ml. Participants who trained } \\
\text { the modulation of desoxy-Hb obtained an } \\
\text { increase in the level of desoxy-Hb in the } \\
\text { inferior frontal gyrus during NF training; The } \\
\text { voluntary modulation of desoxy-Hb had } \\
\text { pronounced cortical activation during Ml and } \\
\text { swallowing ME in the posterior evaluation; } \\
\text { In the oxy-Hb group there were no cortical } \\
\text { changes comparing the pre- and post-NF } \\
\text { evaluations. }\end{array}$ \\
\hline $\begin{array}{c}\text { Kober et al., } \\
\text { (2015a) }\end{array}$ & $\begin{array}{c}\text { The Bogenhauser } \\
\text { Dysphagia Score - } \\
\text { BODS }\end{array}$ & NIRS & $\begin{array}{l}10 \text { swallowing } \mathrm{Ml} \text { sessions and } 10 \\
\text { swallowing ME sessions in randomized } \\
\text { order; Swallowing ME: Instructed to } \\
\text { swallow their saliva two to three times; } \\
\text { In Ml, they are instructed to imagine } \\
\text { swallowing; Each task lasted } 15 \mathrm{~s} \text {; Between } \\
\text { each session, there was a resting moment } \\
\text { signaled by the computer lasting between } \\
\text { 28s and 32s }\end{array}$ & $\begin{array}{c}\text { Inferior frontal } \\
\text { rotation } \\
\text { bilaterally; } \\
\text { Areas of } \\
\text { Brodmann }\end{array}$ & $\begin{array}{l}\text { There were changes in cerebral } \\
\text { hemodynamics in the association between } \\
\mathrm{Ml} \text { and ME during swallowing of dysphagic } \\
\text { patients. Compared with healthy subjects, } \\
\text { there were greater changes in hemodynamics } \\
\text { in the lower frontal gyrus during ME and MI } \\
\text { of patients }\end{array}$ \\
\hline
\end{tabular}

Legend: EMG: Surface electromyography; MI: Motor imagery; ME: Motor performance; NIRS: Near-Infrared Spectroscopy Study; mm: millimeters; L: Liter; s: seconds; Oxy-Hb: Oxyhemoglobin; Desoxy-Hb: Deoxyhemoglobin; EEG: Electroencephalogram; $\mathrm{mL}$ : milliliter; NF: Neurofeedback; min: minutes; MIQ-R: Motor Imagination Questionnaire in the revised version.

Figure 3. Functional evaluations, neuroimaging techniques, motor imagery and brain areas studied in the selected articles

In the search for data in the literature, the selected studies proposed searching the motor imagery of swallowing through different methodologies, and it was not possible to group data by means of statistical analysis. Given this heterogeneity, the results of this study are in the form of a systematic review, without meta-analysis.

The use of motor imagery rehabilitation of swallowing shows to be a recent proposal, since the four selected articles are between the years 2014 and $2015^{6,21-23}$. The literature clearly indicates the efficacy of $\mathrm{MI}$ as an adjuvant in motor rehabilitation of the upper limb in individuals with some neurological disorder ${ }^{25-27}$. But it is incipient the number of articles that suggest this technique correlate with tongue movements, and yet such research does not focus on rehabilitation of swallowing ${ }^{28,29}$.

The countries which have published the research in question are different, however scholars of Austria and the Netherlands give signs that are involved in longitudinal research, improving topic ${ }^{21-23}$. In $2014{ }^{21}$ these researchers approached the use of Ml by neuroimaging technique, checking changes in cerebral hemodynamics. In $2015^{23}$, this same group deepens the methodology with neurofeedback strategies, with training modulation of brain oxygen levels during $\mathrm{MI}$ swallowing. In the other hand, the authors of Singapore ${ }^{6}$ proposed to investigate the detection of swallowing MI as a proposal for rehabilitation through the $\mathrm{Ml}$ of tongue movements (protrusion).

Certainlyi $t$ is presumed that in South American countries, such as Brazil, where the rehabilitation of dysphagia is already consolidated ${ }^{30,31}$, possibly was not yet aroused the intention to enter the Ml approach in clinical practice for the treatment of swallowing changes. Perhaps the limited number of studies will be a barrier to the expansion of this technique in Latin countries.

It is believed that the understanding of the therapeutic approach of the Ml by the speech therapist would enhance new perspectives in dysphagia rehabilitation, considering that the involvement of complex brain functions and knowledgement of swallowing field requires an interdisciplinary action. This is another 
point to be reflected when looking at the departments in wich the four studies of this review were subordinateds (rehabilitation and psychology).

This question is also anchored in the complexity of methodological approaches outlined in each manuscript, different from the selection of the sample to the choice of instruments and stages of Ml execution.

In the sampling, the number of participants in the trials ranged from 6 to 20 individuals, composed mainly of healthy individuals aged up to 35 years. It was assumed that as a recent technique in swallowing rehabilitation, there was the interest of initially study a healthy population, in an attempt to better understanding this therapeutic proposal.

Two studies involved neurological dysfunction ${ }^{6,21}$, wherein 05 patients with stroke, divided into brainstem lesion $(03-60 \%)$ and the middle cerebral artery lesions (02 - 40\%). The time after the event has been described with a range 71-254 days in the study series of cases ${ }^{22}$, and, then considering a sample yet in subacute phase of the disease. Already in the manuscript with a single case of stroke ${ }^{6}$, the patient had chronic injury a year ago.

Lesions in the brainstem often brings changes in swallowing, as well as the interruption of blood flow in the middle cerebral artery can lead to various motorsensory changes, affecting the face and the upper and lower members movements in the contralateral side of encephalic injury ${ }^{32}$. In both studies the focus has permeated to investigate the brain behavior of people with dysphagia during the $\mathrm{Ml}$ and $\mathrm{ME}$ of swallowing, comparing them to individuals without neurological disorders.

In eligibility, for healthy individuals were ruled out any neurological and psychiatric were descarded, as well as sensorial or motor deficit. Moreover, it wouldn't be possible the admission of people with swallowing disorders ${ }^{6,21-23}$. In the other hand, in the participants group with stroke, there was the requirement of dysphagia ${ }^{6,22}$, however with no others neurological and psychiatric disorders, with preserved capacity for understanding and communication ${ }^{22}$.

To check the swallowing function, only one article used standardized assessment Bogenhausen Dysphagia Score (BODs) ${ }^{22}$ to determine the dysphagia degree of the 04 participants with stroke sequelae, classifying them into mild (score 4), moderate (score 5 6), moderate-severe (score 9) and severe (score 11).

The Bods is a German evaluation used by speech therapists in Europe, which assesses the ability to swallow saliva and food intake ${ }^{33}$. The stratification of the population in degree of dysphagia commitment, besides to identify the variability of the sample, raises the researcher concern in the risk analysis, referring the choice of safe intervention strategies to work swallowing rehabilitation. In the survey concerned the water was not used.

The surface electromyography (EMG) of the suprahyoid muscles was used in two manuscripts during $\mathrm{MI}$ swallowing, bringing quantitative data on the electrical activity of these musculature ${ }^{6,21}$. This information was used as a control of active movement (motor) during MI in the swallowing oral phase.

In the analysis of the supra-hyoid muscles ${ }^{21}$, the researchers identified that the electrical activity of these muscles increased during the execution of the movement compared with the $\mathrm{Ml}$ and rest. There was also a numerical increase (not statistically significant) in electrical activity during the Ml when compared with rest. In discussion, it quotes the hypothesis that the reducing of the electrical signal magnitude during the $\mathrm{MI}$ has roots in cortical inhibition of movement (motor control) while the MI.

Studies show similarity in activation of brain areas during $\mathrm{ME}$ and $\mathrm{MI}$, highlighting the Primary Motor (M1), Supplementary Motor Area (SMA), Pre-Motor and somatosensory cortex in the parietal lobe ${ }^{15,16}$. However, the suppression exerted by the SMA to the M1 during MI has also been reported in other studies 15,17. It is believed that this inhibitory effect is a physiological mechanism to prevent movement during the MI.

To find out if the study population was understanding the technique of motor imagery, a single article used the Motor Imagination Questionnaire in the revised version - MIQ-R ${ }^{23}$. This questionnaire is the most used to verify, through scores, the ability to imagine a movement through a visual or kinesthetic strategy, involving movements of the leg, arm and whole body ${ }^{34}$.

The neuroimaging technique most widely used was the Near-Infrared Spectroscopy - NIRS (03-75\%) ${ }^{21-23}$ by the researchers group from Austria and Netherlands. The infrared spectroscopy (NIRS) is one of the main techniques used to observe tissue oxygenation, most specifically the oxyhemoglobin flow $(\mathrm{Oxy}-\mathrm{Hb})$ and deoxyhemoglobin (Hb-Desoxy) in muscle and brain regions ${ }^{35}$. The change in blood oxygenation response to a stimulus reflects in a higher level of brain activation, that is, in the area where most cortical activation occurs there is alteration in blood flow and volume, can be 
monitored, by NIRS, the concentrations of oxy- and deoxyhemoglobin. In this review, the authors proposed verify this change of cerebral hemodynamics in Brodmann areas, focusing on the inferior frontal gyrus, during the execution and imagination of the swallowing moviments.

With healthy individuals ${ }^{21}$, the NIRS results corroborate other neuroimaging studies about activation of premotor areas and SMA during the ME and MI ${ }^{15,17}$. There was an increase of oxy-Hb during ME (swallowing water) and Desoxy-Hb had greater concentration during the tasks than in the rest. During the motor execution would be expected the increase of the oxy- $\mathrm{Hb}$ flow and the inhibitory mechanism during Ml, discussed above, may be a hypotesis for these hemodynamic changes. On the other hand, it was not possible on these results make inferences for the population with neurological alterations nor propose ways of treatment.

The oxygen flow modulation was aimed through the use of NIRS and neurofeedback ${ }^{23}$. The participants were divided into two groups (oxy- and desosy- $\mathrm{Hb}$ ) and instructed to observe a white dot on a computer screen with green and gray color stripes. The volunteer should imagine swallowing water depending on the color of the stripe in which the white point it was positioned.

For neurofeedback training, different values of oxy- or desoxy-Hb (respectively in each group) were achieved in the inferior frontal gyrus, being represented by changes in the vertical direction of the white spot on the screen. The results showed that levels of oxy- and desoxy-Hb increases during both $\mathrm{Ml}$ and ME. In the group of individuals who have trained the desoxy- $\mathrm{Hb}$ modulation, obtained an increase in the desoxy-Hb level in the inferior frontal gyrus. This study proposed intervention and the possibility of cortical reorganization, although it was carried out with healthy individuals.

In 2013, a pilot study used the NIRS with the neurofeedback proposal in motor imagery of post-stroke patients, confirming to be possible a cortical reorganization in neurological patients, with enhancement of functional recovery during rehabilitation. However, in this study the imagined movements were restricted to the upper member and has not been further analyzed the swallowing function ${ }^{36}$.

The NIRS study with neurological patients ${ }^{22}$ showed the occurrence of hemodynamic changes in the $\mathrm{Ml}$ and ME of swallowing in patients with dysphagia and in a more pronounced form, in the inferior frontal gyrus, reinforcing the possibility to rehabilitate this function through the MI. In the inferior frontal gyrus is located the Broca's area, largely responsible for the language, and is also situated the control of orofacial sensory motor movements unrelated to speech, going on activation during swallowing ${ }^{37}$.

The authors of Singapore ${ }^{6}$ corroborate the idea of rehabilitating dysphagia through swallowing of MI. In this study with electroencephalogram (EEG), the MI of tongue movements was used as a model for the detection of MI swallowing. The study has proposed that brain areas responsibless for swallowing are activated during the lifting movement of the tongue and quotes the cingulate cortex and the supplementary motor area.

The literature points out that the extent and distribution of brain activations may differ in Ml and ME, however in both the $\mathrm{Ml}$ and the execution activities, the neural networks involving central motor areas are activated. These areas participate in the planning, initiation and execution of motor commands ${ }^{38}$. The supplementary motor area along with pre motor cortex send neural impulses to the primary motor cortex and are constantly activated during $\mathrm{MI}$ and $\mathrm{ME}$. In addition, the synchronization and coordination of the swallowing movements, is already evident in the literature the association of cortical areas such as the insula and pre motor cortex ${ }^{5}$.

In consonance, study about the brain activation and connections that occurs during motor imagery indicates that the primary motor cortex, supplementary motor area and prefrontal cortex plays a crucial role during the $\mathrm{Ml}$ and $\mathrm{ME}$. The interaction between brain areas and effective network connectivity shows the importance of relationship of treatment as a mental practice and physical therapies during motor rehabilitation ${ }^{39}$.

In the event of neurological disorders, the MI associated with ME strengthens the occurrence of connections in the cortical motor area on the affected brain side and rearranges the connectivity of neural network of the contralateral cerebral side to the lesion ${ }^{40}$, in the case of an effective strategy in dysphagia rehabilitation, since that the cortical representation of normal swallowing is bilateral ${ }^{19}$.

In this study ${ }^{6}$, it is suggested that in clinical practice, the swallowing or tongue $\mathrm{Ml}$ can be used in the rehabilitation of swallowing in common situations, such as weak swallowing, for examples in patients with post-stroke dysphagia, as well as in those individuals who have late start swallowing, reducing the lag time at 
the beginning of the pharyngeal phase and avoinding situations related to escape and aspiration.

However, it indicates the difficulty of accomplishing the $\mathrm{Ml}$ swallowing due to the complexity of the movement that involves sensory processing, coordination of chewing movements, breathing and attention. As the study realized with NIRS, it requires a larger number of participants to raise inference to the general population and facilitate the incorporation of the technique as an adjuvant of the conventional ${ }^{22}$ swallowing rehabilitation.

\section{CONCLUSION}

The studies suggest that the motor imagery may cause some brain response in the motor area of the brain, suggesting that mentalization of actions related to swallowing may be effective to improve the engine performance of this function and therefore, reflecting also, in the feeding activity. However, new studies are needed with a larger number of participants allowing introducing this technique in the clinical intervention of professionals involved in swallowing rehabilitation.

\section{REFERENCES}

1. Matsuo K, Palmer JB. Anatomy and physiology of feeding and swallowing - normal and abnormal. Phys Med Rehabil Clin N Am. 2008;19(4):691-707. Doi: 10.1016/j.pmr.2008.06.001.

2. Yamada EK, Siqueira KO, Xerez D, Koch HA, Costa MMB. A influência das fases oral e faríngea na dinâmica da deglutição. Arq Gastroenterol. 2004;41(1):19-23.

3. Ramsey DJC, Smithard DG. Assessment and management of dysphagia. Hosp Med. 2004;65(5):274-9.

4. Barritt AW, Smithard DG. Role of cerebral cortes plasticity in the recovery of swallowing function following dysphagic stroke. Dysphagia. 2009;24(1):83-90.

5. Sessle BJ, Yao D, Nishiura H, Yoshino K, Lee JC, Martin RE et al. Properties and plasticity of the primate somatosensory and motor córtex related to orofacial sensorimotor function. Clin Exp Pharmacol Physiol. 2005;32(1-2):109-14.

6. Yang H, Guan C, Chua KSG, Chok SS, Wang $\mathrm{CC}$, Soon PK et al. Detection of motor imagery of swallow EEG signals based on the dual-tree complex wavelet transform and adaptive model selection. J. Neural Eng. 2014;11(3):1-13.
7. Duncan PW, Zorowitz R, Bates B, Choi JY, Glasberg $\mathrm{JJ}$, Graham GD et al. Management of adult stroke rehabilitation care: a clinical practice guideline. Stroke. 2005;36(9):100-43.

8. Kleim JA, Jones A. Principles of experiencedependent neural plasticity: implications for rehabilitation after brain damage. J Speech Lang Hear Res. 2008;51(1):S225-39.

9. Sharma N, Pomeroy VM, Baron JC. Motor imagery: a backdoor to the motor system after stroke? Stroke. 2006;37(7):1941-52.

10. Jackson PL, Doyon J, Richards CL, Maloui F. The efficacy of combined physical and mental practice in the learning of a foot-sequence task after stroke: a case report. Neurorehabilitation Neural Repair. 2004;18(2):106-11.

11. Schuster C, Butler J, Andrews B, Kischka U, Ettlin T. Comparison of embedded and added motor imagery training in patients after stroke: study protocol of a randomised controlled pilot trial using a mixed methods approach. Trials. 2009;10(1):97.

12. Jackson PL, Lafleur MF, Malouin F, Richards C, Doyon J. Potential role of mental practice using motor imagery in neurologic rehabilitation. Arch Phys Med Rehabil. 2001;82(8):1133-41.

13. Liu K, Chan C, Lee TM, Hui-chan CW. Mental imagery for promoting relearning for people after stroke: a randomizes controlled trial. Arch Phys Med Rehabil. 2004;85(9):1403-8.

14. Machado A. Neuroanatomia Funcional. Editora Atheneu, 2a ed. 2006.

15. Gao Q, Duan X, Chen H. Evaluation of effective connectivity of motor areas during motor imagery and execution using conditional Granger causality. Neuroimage. 2011;54(2):1280-8.

16. Guillot A, Collet C. Contribution from neurophysiological and psychological methods to the study of motor imagery. Brain Res Rev. 2005;50(2):387-97.

17. Kasess $\mathrm{CH}$, Windischberger $\mathrm{C}$, Cunnington R, Lanzenberger R, Pezawas L, Moser E. The suppressive influence of SMA on M1 in motor imagery revealed by $\mathrm{fMRI}$ and dynamic causal modeling. Neuroimage. 2008;40(2):828-37.

18. Brown CE, Li P, Boyd JD. Delaney KR, Murphy TH. Extensive turnover of dendritic spines and vascular remodeling in cortical tissues recovering from stroke. J Neurosci. 2007;27(15):4101-9. 
19. Hamdy S, Aziz Q, Rothwell JC. The cortical topography of humam swallowing musculature in health and disease. Nat Med. 1996;2(11):1217-24.

20. Ataliah AN, Castro AA. Revisão Sistemática da literatura e Metanálise. In: Ataliah AN, Castro AA (orgs). Medicina baseada em evidências: fundamentos da pesquisa clínica. São Paulo: Lemos Editorial; 1998. p.20-8.

21. Kober SE, Wood G. Changes in hemodynamic signals accompanying motor imagery and motor execution of swallowing: A near-infrared spectroscopy study. Neuroimage. 2014;93(1):1-10.

22. Kober SE, Bauernfeind G, Woller C, Sampl M, Grieshofer P, Neuper C et al. Hemodynamic signal changes accompanying execution and imagery of swallowing in patients with dysphagia: a multiple single-case near-infrared spectroscopy study. Front. Neurol. 2015;6:151. doi: 10.3389/ fneur.2015.00151

23. Kober SE, Gressenberger B, Kurzmann J, Neuper C, Wood G. Voluntary modulation of hemodynamic responses in swallowing related motor areas: $A$ near-infrared spectroscopy-based neurofeedback study. Plos One. 2015;10(11):e0143314. doi:10.1371/journal.pone.0143314.

24. Moher D, Liberati A, Tetzlaff J, Altman DG., The PRISMA Group. Preferred reporting items for systematic reviews and meta-analyses: The PRISMA Statement. Disponível em: www.prismastatement.org. Acesso em: 20 de maio de 2016.

25. Braun SM, Haastregt LCV, Beurskens AJ, Gielen AI, Wade DT, Schols JM. Feasibility of a mental practice intervention in stroke patients in nursing homes; a process evaluation. Neurology. 2010;10(1):1-9.

26. Bastos AF, Carrapatoso BC, Orsini M, Leite MAA, Silva JG, Souza GGL. Functional recovery of upper limb post-stroke: mental practice with motor and non-motor imagery. Am Medic J. 2012;3(1):50-5.

27. Page SJ, Dunning K, Hermann V, Leonard A, Levine $P$. Longer versus shorter mental practice sessions for affected upper extremity movement after stroke: a randomized controlled trial. Clin Rehabil. 2011;25(7):627-37.

28. Morash V, Bai O, Furlani S, Lin P, Hallett $M$. Classifying EEG signals preceding right hand, left hand, tongue and right foot movements and motor imageries. Clin Neurophysiol. 2008;119(11):2570-8.

29. Pfurtscheller G, Brunner C, Schlogl A, Silva FHL. Mu rhythm (de)synchronization and EEG single-trial classification of different motor imagery tasks. Neurolmage. 2006;31(1):153-9.

30. Itaquy RB, Favero SR, Ribeiro MDE C, Barea LM, Almeida ST, Mancopes R. Dysphagia and cerebrovascular accident: relationship between severity degree and level of neurological impairment. J Soc Bras Fonoaudiol. 2011;23(4):385-9.

31. Steimbergtu C, Frazãot YS, Furmm AM. Disfagia no Brasil : a construçao de uma pratica. Rev. CEFAC 2003;5(2):117-25.

32. Lundy-Ekman L. Neurociência: Fundamentos para reabilitação. Editora Elsevier. 3a ed. 2008.

33. Schiele JT, Penner $H$, Schneider $H$, Quinzler $\mathrm{R}$, Reich G, Wezler $\mathrm{N}$ et al. Swallowing tablets and capsules increases the risk of penetration and aspiration in patients with stroke-induced dysphagia. Dysphagia. 2015;30(5):571-82. http:// dx.doi.org/10.1007/s00455-015-9639-9

34. Gregg M, Hall C, Butler A. The MIQ-RS: A suitable option for examining movement imagery ability. Evid Based Complement Alternat Med. 2010;7(2):249-57.

35. Lima A, Bakker J. Espectroscopia no infravermelho próximo para a monitorização da perfusão tecidual. Rev Bras Ter Intensiva. 2011;23(3):341-51.

36. Mihara M, Hattori N, Hatakenaka M, Yagura $H$, Kawano T, Hino T. Near-infrared spectroscopymediated neurofeedback enhances efficacy of motor imagery-based training in poststroke victims a pilot study. Stroke. 2013;44(4):1091-8.

37. Hirsch J, Ruge MI, Kim KHS, Correa DD, Victor JD, Relkin NR et al. Integrated functional magnetic resonance imaging procedure for preoperative mapping of cortical areas associated with tactile, motor, language, and visual functions. Neurosurgery. 2000;47(3):711-22.

38. Bajaj S, Butler AJ, Drake D, Dhamala M. Oscilatory motor network activity during rest and movemen: an fNIRS study. Front. Syst. Neurosci. 2014;8(13): 1-12. http://dx.doi.org/10.3389/ fnys.2014.0001324550793.

39. Bajaj S, Butler AJ, Drake D, Dhamala M. Brain effective connectivity during motor-imagery and execution following stroke and rehabilitation. Neuroimage. 2015; 8(1):572-82.

40. Ertekin C, Aydogdu I, Yüceyar N, Tarlaci S, KiyliogluN, Pehlivan $\mathrm{M}$ et al. Electrodiagnostic methods for neurogenic dysphagia. Electroencephalogr Clin Neurophysiol. 1998;109(4):331-40. 